\title{
Kafka's Reality and Nabokov's Fantasy. On Dwarves, Saints, Beetles, Symbolism, and Genius.
}

\section{Citation}

De La Durantaye, Leland. 2007. Kafka's reality and Nabokov's fantasy: On dwarves, saints, beetles, symbolism, and genius. Comparative Literature 59, no. 4: 315-331.

\section{Published Version}

http://www.uoregon.edu/ clj/DurantayeAbstract.html

\section{Permanent link}

http://nrs.harvard.edu/urn-3:HUL.InstRepos:3374612

\section{Terms of Use}

This article was downloaded from Harvard University's DASH repository, and is made available under the terms and conditions applicable to Other Posted Material, as set forth at http:// nrs.harvard.edu/urn-3:HUL.InstRepos:dash.current.terms-of-use\#LAA

\section{Share Your Story}

The Harvard community has made this article openly available.

Please share how this access benefits you. Submit a story.

\section{Accessibility}




\section{Kafka's Reality and Nabokov's Fantasy. On Dwarves, Saints, Beetles, Symbolism, and Genius}

\section{The Metamorphosis}

It is not difficult to hear echoes of Kafkan steps in the early works of Vladimir Nabokov. Critics have detected faint echoes in his early Russian novels The Eye (1930) and Despair (1933) (see Hyde 104, 109; and Foster) and more definite sounds in Invitation to a Beheading (1938). In the latter novel, a harmless hero in an abstracted world is interred in a castle, brought before an incomprehensible tribunal, and charged with the vaguest of crimes ("Gnostic turpitude"). This thematic similarity was strong enough for Nabokov to protest in a 1959 foreword to the English translation of the novel that he had not read Kafka until after he wrote it (Invitation 6). When asked about the matter in an interview ten years later, he replied: "I do not know German and so could not read Kafka before the nineteen thirties when his La métamorphose appeared in La nouvelle revue francaise, and by that time many of my so-called 'kafkaesque' stories had already been published" (Strong Opinions 151-52).

In Bend Sinister (1947), the first novel Nabokov wrote in America, a beetleshaped bootjack is referred to as Grégoire (the name Kafka's protagonist bears in La métamorphose), and, more to the Kafkan point, the novel not only includes a miraculous transformation in its closing lines, but also depicts a nightmarish world of absurd bureaucracy that at certain shadowy moments recalls Kafka (Bend Sinister 33-34; cf. also Foster 445). And in Nabokov's final novel, Look at the Harlequins! (1974), when the protagonist Vadim Vadimorovitch (a special refraction of Vladimir Vladimirovitich [Nabokov]) provides a list of his works that darkly mirrors Nabokov's own, the novel corresponding to Invitation to a Beheading on the narrator's CV is entitled The Red Topper, which tells of "the strange pangs of a strange transformation"-a description that displaces one Kafkan world (that of castle and court) for another (that of a metamorphosis) (Harlequins 120).

Whether Nabokov was wrong in his estimations of Kafka's influence, or mischievously misleading about the date of his first familiarity, cannot be answered 
with certitude. But they are not the only questions we might pose. Though critics have been most attracted by the sport of potential influence, ${ }^{1}$ in the following I argue that there are other and more interesting grounds for studying Nabokov's reflections on Kafka and that these are to be found in Nabokov's singular interpretation of The Metamorphosis and what that interpretation has to say about his rules for good reading and good writing.

\section{Dwarves and Saints}

Nabokov lived in Berlin from 1922 to 1937 and over the course of those eighteen years seems to have concerned himself as little as possible with German language, culture, politics-and Germany itself. Besides the lessons he gave in tennis, boxing, French, English, and Russian-lessons that allowed him and his family a precarious subsistence-his social and intellectual activity remained solidly within the sphere of Berlin's Russian émigré community (then the largest in Europe and only to be eclipsed by that of Paris in the mid 1930s). Though as a youth Nabokov had known enough German to translate short poems by Heine and Goethe into Russian, he later claimed to have next to no working knowledge of the language and that he had resisted acquiring one out of fear that it might lead to his losing touch with his native Russian. "Upon my moving to Berlin," he later remarked, "I was beset by a panicky fear of somehow flawing my precious layer of Russian by learning to speak German fluently" (Strong Opinions 189; cf. Lectures $\mathrm{xx}$ ). Nevertheless, he notes that "I read Goethe and Kafka en regard" (Strong Opinions 189). ${ }^{2}$

Despite his best efforts, Nabokov did not, however, remain indifferent to contemporary German literature. He developed strong-and mostly negative-opinions that he was not shy about voicing. His chief object of scorn was German literature's most celebrated novelist, Thomas Mann, with the language's most celebrated modern poet, Rainer Maria Rilke, a close second. In the years of his growing fame, Nabokov rarely neglected to include Mann-alongside such figures as Gide, Faulkner, Balzac, and Dostoevsky-in litanies of renowned novel-

${ }^{1}$ Specifically referring to Kafka, Nabokov remarked, "alas, I am not one to provide much sport for influence hunters" (Strong Opinions 152). Cf. also Foster's comment that "by an ingenious irony ... the very indirectness of Kafka's role suggests a relationship that is 'metamorphic' in its own right" (445).

${ }^{2}$ For a general overview of Nabokov's works and days during these years, see Field, Boyd, and Schiff. Further background-in both text and image-can be found in Zimmer and Urban. The latter succinctly notes of Nabokov: "In keine andere Sprache wurden seine Werke häufiger übersetzt als ins Deutsche. Doch handelt es sich hierbei um eine höchst einseitige Bewunderung" (9; Into no other language have Nabokov's works been more often translated than German. And yet, this has been a very one-sided admiration ). Interest in German influences-literary and other-on Nabokov's work has been recently intensified through the discovery of an obscure short story entitled "Lolita," published in 1916 by a Hessian aristocrat named Heinz von Eschwege under the pseudonym Heinz von Lichberg, a story which (in addition to the title) has certain thematic similarities with Nabokov's famous novel. Its existence was noted by the German journalist Michael Maar (see "Was wußte Nabokov?"), who later summarized his findings for the English reading public in "Curse of the First Lolita. Heinz von Lichberg and the Pre-history of the Nymphet" and The Two Lolitas. 
ists whom he deemed "mediocrities." In 1945, an indignant Nabokov wrote to his dear friend (later to become a bitter enemy) Edmund Wilson, "How could you name that quack Mann in one breath with $\mathrm{P}$ [roust] and J[oyce]? (NabokovWilson 148). In "On a Book Entitled Lolita," written in 1957, Nabokov refers to "topical trash or what some call the Literature of Ideas" and lists as examples of such Balzac, Gorki, and Mann (Annotated Lolita 315). In an interview for the German weekly Die Zeit in 1959, after Nabokov had run down Mann once again, his interviewer asked him if there were any German authors he did like. The answer apparently "came without the slightest hesitation": "Franz Kafka. But not the mystical image of Kafka that has been erected by his friends but the real Kafka. I consider him one of the greatest European authors of our time, and I can always read and reread works like The Metamorphosis or The Castle" ("Wer ist der LolitaAutor" 6). ${ }^{4}$

Though Nabokov's abuse was better known than his praise, he had been expressing this view of Kafka to the widening circles of his students at Wellesley, Harvard, Stanford, and Cornell for nearly twenty years. Nabokov said each year in his lectures on European masterpieces that Kafka was "the greatest German writer of our time" and that "such poets as Rilke or such novelists as Thomas Mann are dwarfs or plaster saints in comparison to him" (Lectures 255). He even seemed to derive special pleasure from the vicinity in which they briefly lived-noting for his class how Kafka "in those last years of his short life ... had a happy love affair and lived with his mistress in Berlin, in 1923, not far from me" (255). In an interview from 1965, after the success of Lolita and the conveniences of Switzerland led Nabokov permanently to suspend his lectures on literature, he drew up a personal list of "the greatest masterpieces of twentieth-century prose," wherein Kafka's The Metamorphosis appeared in second place behind Joyce's Ulysses (Strong Opinions 57). ${ }^{5}$

There is indeed nothing extraordinary in any of this. Neither Mann's talent nor Rilke's was so universal that every sensitive reader championed it, and-for all the breadth of Mann's talent and all the depth of Rilke's-each writer had intelligent and sensitive detractors. There is even less matter for surprise in Nabokov's rating Kafka's literary genius as amongst the greatest of the twentieth century or finding The Metamorphosis his best work. ${ }^{6}$ Finally, there is nothing

\footnotetext{
'Foster astutely speculates that it was Nabokov's discovery, after he arrived in America, that Mann was a highly praised figure there that led him to attack his fellow novelist in exile even more vehemently and more publicly than he had before (446). For an example of Nabokov's ridicule of Mann while he was still in Europe, consider the title of one of the mischievous Sebastian Knight's books, "The Funny Mountain" (cf. The Real Life of Sebastian Knight).

${ }^{4}$ Translation by Dieter Zimmer. My thanks to Dieter Zimmer for bringing this interview to my attention and helping me to locate it.

${ }^{5}$ Foster notes that when in Strong Opinions Nabokov points out his "top favorites" from the period of 1919-1939, he makes no mention of Kafka (445). At the same time, Foster traces in detail the Kakfan notes struck in such works as Bend Sinister and Look at the Harlequins! (447-50).

${ }^{6}$ To pick a celebrated example, Elias Canetti argues that "In The Metamorphosis Kafka reached the height of his mastery: he wrote something which he could never surpass, because there is nothing which The Metamorphosis could be surpassed by" (22-23). It is interesting to note that Kafka himself did not find it his best work. As his letters to Felice Bauer from the end of 1912 chronicle, he particularly disliked the story's ending and blamed numerous flaws in its composition on a business trip that interrupted his feverish composition.
} 
extraordinary in Nabokov's expressing an elective affinity for an author from a tradition in which, as a rule, he found little that was kindred to him. What is extraordinary is the fruit of Nabokov's admiration. Before leaving Europe, Nabokov composed the lectures on literature which were to sustain him so long and so well in the New World (and which were published after his death). ${ }^{7}$ Therein, Kafka is placed alongside Austen, Dickens, Flaubert, Stevenson, Proust, and Joyce for special study and praise. What is surprising is that the lectures dedicated to Kafka proved to be the most idiosyncratic and incomplete-simply stated, the poorest-of the group. Despite sparks of sympathy and wit, they show Nabokov throwing interpretative caution to the wind and openly violating the instructions he gives elsewhere on how to read great works. The goal of the following will be to uncover how and why he did this.

\section{Handbags, Train Compartments, and the Imaginal Stage}

The most curious aspects of Nabokov's reading of Kafka's work concern his symbolic interpretation of the details of that work. So as to present these in the proper light I must make a brief detour through Nabokov's general remarks on the specific role of details in the work of art. His position is simply stated: he prized the particular above all else. In the introductory remarks to his Lectures on Literature, Nabokov proclaims that "in reading, one should notice and fondle details" (1). In the 1958 Course Description for a lecture course at Cornell we read that the works in the class will be "studied from the point of view of structure and style with great attention given to technical details and factual, specific features" (qtd. in Selected Letters 238; my italics). The course's final examination asked students to describe Emma Bovary's sunshade and shoes, to enumerate the contents of Anna Karenina's handbag, and to map the Liffey's movement through Dublin. ${ }^{8}$

Nabokov's emphasis on literary detail was not merely a pedagogical approach. In a letter to Wilson from 1946, Nabokov harshly criticizes André Malraux's $L a$ condition humaine on the grounds that he found it unlikely that mosquitoes in the "imaginal stage" were to be found in early spring in Shanghai-an oversight that leads him to class Malraux as a "third-rate writer" (Nabokov-Wilson 175-76). In another letter to Wilson, Nabokov criticizes Henry James's "The Aspern Papers" because the narrator refers to the "red tip" of a cigar seen by night from a

\footnotetext{
${ }^{7}$ Despite Nabokov's express wishes to the contrary (a note in Nabokov's hand in the Nabokov Archive in the New York Public Library attests to this), his Lectures on Literature, along with his Lectures on Russian Literature and Lectures on Don Quixote, were, with the approval of his wife and son, published posthumously. They do not, however, represent unpolished or unfinished work. Nabokov composed the lectures in preparation for an academic career and refined and revised them during his first decade in America. At several points during the last decade of his life Nabokov also voiced an intention to prepare the lectures for publication. Failing to respect last literary wishes is of course nothing new. Kafka's wish that all his unpublished material remain so-and, in fact, be burned-was refused by his literary executor Max Brod.

${ }^{8}$ Some of these exam questions are reproduced in the appendix to Lectures on Literature (38385). Further exam questions can be found in the Nabokov Collection in Kroch Library at Cornell University.
} 
darkened window. Nabokov objects that the light of a cigar by night is "blunt," and dismissively suggests that the locution would more aptly describe a dog's penis-an observation that reinforces his disparaging view of James's work in that letter (53). Gentle souls from Nabokov's novels such as The Gift's Fyodor or The Defense's Luzhin (who is thrilled by "Sherlock composing a monograph on the ash of all known sorts of cigars"; cf. Defense 34) are blessed with precisely such attentiveness to detail-as are the darker and more complicated cases of Humbert in Lolita and Ada and Van Veen in Ada, or Ardor. For Nabokov, the province of art was the province of the particular detail. "In high art and pure science," he said, "detail is everything" (Strong Opinions 168).

This prizing of detail led Nabokov to take issue with two tendencies that he found to be unconditionally pernicious in the world of art. The first was the recourse to mythological symbols. Speaking of his teaching days at Cornell, Nabokov proudly related, "Every time one of my students used the word 'symbol' in a paper, I gave them a bad grade" ("je donnais une mauvaise note chaque fois qu'ils employaient le mot "symbole," Interview with Pierre Dommergues 97). Similarly, he later reminisced, "I once gave a student a C-minus, or perhaps a Dplus, just for applying to [Joyce's Ulysses] the titles borrowed from Homer" (Strong Opinions 55). This recourse to mythological signs or symbols was something he did not like in Joyce's writings and loathed in writers towards whom he felt less inclined, such as T.S. Eliot.

The second tendency that in Nabokov's view occluded the prized details of his treasured texts was what in "Conclusive Evidence" he denounces as "the oneiormancy and mythogeny of psychoanalysis" (133). The opening paragraphs of both of the first two chapters of his autobiography condemn as ringingly as possible, "the vulgar, shabby, fundamentally medieval world" of Freud's thought (Speak, Memory 20), and in the screenplay for Lolita "the Freudian prison of thought" and "the Freudian nursery-school of thought" are both vehemently evoked and dismissed. Ada, or Ardor likewise abounds in references to the "expensive confession fests" of psychoanalysis"(364), and Strong Opinions laments the incursions of "the Austrian crank with a shabby umbrella" (116).

This, in its general outline, was Nabokov's position on the particular detail and the artistic attention that should be paid to it. ${ }^{9}$ But before we turn to Nabokov's treatment of Kafka's tale, we must make a final detour into the realm of the fairy tale.

\section{Fairy Tales}

"The truth," Nabokov says at the outset of his Lectures on Literature, "is that great novels are great fairy tales" (2). Later he states that "Mansfield Park is a fairy tale, but then all novels are, in a sense, fairy tales" $(10)$. What did he mean by this curious declaration? Given the list of works Nabokov discusses in the lectures, the suggestion is a surprising one. The first three authors studied in the course are founding figures in the realist tradition: Austen, who endeavored to

\footnotetext{
${ }^{9}$ For more on this and related points, see de la Durantaye $147 \mathrm{ff}$.
} 
reproduce and reflect the England of her day with a psychological veracity and geographical fidelity verging on the documentary; Dickens, who so carefully describes the movements of his characters in Bleak House-the novel Nabokov discusses in his course-that those movements can be followed around every corner of the London of the day; and Flaubert, who spent days taking coach rides through a Normandy he loathed so as to time the various routes for use in Madame Bovary. Even in the case of the more experimental works such as those of Proust to be discussed later in the semester, Nabokov is well attuned to realist elements. The same is true for Joyce's Ulysses, which, for all its formal experimentations, still leads passionate literary pilgrims every June 16th around Dublin, following in the hallowed footsteps of the characters. (Joyce was only half joking when he claimed that his book would allow Dublin to be rebuilt from scratch should a cataclysm befall the city.) While there were indeed two works taught in the course -Stevenson's Dr. Jekyll and Mr. Hyde and Kafka's The Metamorphosis-with a significant dose of the fantastic, those works are nonetheless not fairy-tales, and both owe much of their eeriness to the psychological and descriptive realism that surrounds the impossible transformations they recount. ${ }^{10}$ From this we must conclude that Nabokov meant his generic declaration that "all great novels are great fairy tales" in a singular and special sense.

In the Introduction to Bend Sinister Nabokov writes: "I am not 'sincere,' I am not 'provocative,' I am not 'satirical.' I am neither a didacticist nor an allegorizer. Politics and economics, atomic bombs, primitive and abstract art forms, the entire Orient, symptoms of 'thaw' in Soviet Russia, the Future of Mankind, and so on, leave me supremely indifferent" (xii). How is one to take such blanket dismissals? There is of course a great deal of bluster in these statements, but that is not all that is to be found there. In his list of reading instructions for Dickens's monumental Bleak House, number five reads: "The sociological side [of the novel], brilliantly stressed for example by Edmund Wilson in his collection of essays The Wound and the Bow, is neither interesting nor important" (Lectures 68). Hitting close to home (his and ours), he enjoins his reader to "remember that literature is of no practical value whatsoever, except in the very special case of somebody's wishing to become, of all things, a professor of literature" (125). Or as Nabokov wrote to Wilson in 1956, "I . . . think that at a time when American readers are taught from high school on to seek in books 'general ideas' a critic's duty should be to draw their attention to the specific detail, to the unique image, without which ... there can be no art, no genius, no Chekhov, no terror, no tenderness, and no surprise" (Nabokov-Wilson 298).

With these remarks in mind we can clarify what Nabokov meant by his curious statement that "all great novels are great fairy tales." It seems that what he was striving to say with the remark was something not about how great novels were written, but about how they should be read. Just as we do not judge fairy tales by how accurately they reproduce a world we know - that is, we do not criticize fairy

\footnotetext{
${ }^{10}$ Milan Kundera famously claimed that what was really unsettling in Kafka's work was not that it was fantastic, but that it was realist. Similarly, when asked who his favorite novelists were, Italo Calvino included Kafka in his list, with this annotation: "I love Kafka because he is a realist [perché è realista]" (35).
} 
tales because, for instance, there are no bridges under which trolls dwell-so Nabokov does not wish his "good readers" to judge Austen, Dickens, Flaubert, Stevenson, Proust, Joyce, or Kafka on the basis of how accurately they reflect the psychology and values of specific persons in the landscape of a specific place at a specific time. Austen, Dickens, and Flaubert, to pick the first writers read in the course, may indeed be quite accurate in their reproductions of life in certain places at certain times, but that is not what Nabokov wants his readers to read for. Literature, for him, should be studied as literature and not for the better understanding of some other thing-be it history, psychology, or landscape architecture. Simply stated, he wants his students to study the works in question not as documents but as works. To say that great novels should be read as great fairy tales is therefore to issue a rule of readerly caution: we should concern ourselves as little with the "real" people or "real" places standing behind or beyond the works of even the most realistic of all genres-the novel-as we would if they were fairy tales.

\section{Finding Fantasy and Inventing Reality}

Nabokov thus warns against reading "realist" masterpieces such as Mansfield Park, Bleak House, and Madame Bovary in a realist way. He fears that such an approach will limit the depth and breadth of the reader's experience. But what of a case where the temptation to read realistically is less strong? Although a reader may happen or come to know a fair amount about life in nineteenth-century English manor houses or the Norman countryside, or perhaps may have studied the baroque functioning of the courts of Chancery or wandered the winding streets of London, a reader (we can only hope) will not know much about awakening one morning transformed into a giant insect. And so, in the case of Kafka, Nabokov's injunction seems a less pedagogically pressing one. Nevertheless, his lecture on Kafka begins with an excursus on "fantasy."

"From my point of view," says Nabokov, "any outstanding work of art is a fantasy insofar as it reflects the unique world of a unique individual" (Lectures 252). What, however, does he mean by this statement? The ample place he accords to "fantasy" is a direct result of the narrow space he accords to "reality." "Reality," he says, is always only "what is commonly called reality" (252). Kafka's The Metamorphosis is then-plausibly enough - called a "fantasy." This claim can be seen in a broader light, however, when one bears in mind that in his lecture on Proust Nabokov will say of In Search of Lost Time that "it is not a mirror of manners, not an autobiography, not a historical account. It is pure fantasy on Proust's part, just as Anna Karenin is a fantasy, just as Kafka's The Metamorphosis is fantasy-just as Cornell University will be a fantasy if I ever happen to write about it some day in retrospect" (210; my italics).

But what precisely does he mean by "fantasy"? This is best glimpsed by looking at fantasy's more reputable twin, "reality." In Nabokov's universe, "life does not exist without a possessive epithet," because "all reality is comparative reality" (Strong Opinions 118; Lectures 146). In an interview with Pierre Dommergues, Nabokov remarks: "Le mot réalité est le plus dangereux qui soit . . . La réalité de l'art? C'est une réalité artificielle, une réalité crée, qui ne reste réalité que dans le roman. Je 
ne crois pas qu'il y ait de réalité objective" (95; "The word 'reality' is the most dangerous word there is ... The reality of art? It is an artificial, a created reality that is only reality within the novel. I do not believe in such a thing as objective reality"). Humbert Humbert tells us that "reality" is "one of the few words which mean nothing without quotes" (Annotated Lolita 312), and Nabokov concurs with him when he speaks of "such local ingredients as would allow me to inject a modicum of average 'reality' (one of the few words which mean nothing without quotes) into the brew of individual fancy" (Strong Opinions 94). It should come then as no surprise that Nabokov states in the Apostrophes interview that the America of Lolita (which so many critics had praised for its realism) was as "imaginary" as the fantastical Antiterra of his later novel Ada, or Ardor.

This is far from a pose limited to Nabokov's non-fictional or occasional writing. In the third canto of his 999-line poem "Pale Fire" (the poem around which the novel of the same name grows), Shade refers to a certain "vision" that "reeked with truth" and "had the tone,/The quiddity and quaintness of its own/Reality" (Pale Fire 60). That "reality" denotes not a common perceptual field or substance, but the most radically subjective experience is reflected in Ada's "metaphysics" by her use of "reality" to denote only the most rare and personal of experiences (Ada 74). Her father likewise believes that the ability to perceive this "reality" requires what he calls "that third sight (individual, magically detailed imagination) ... without which memory (even that of a profound 'thinker' or technician of genius) is, let us face it, a stereotype or a tear-sheet" (252). "To be sure," Nabokov allows, "there is an average reality, perceived by all of us, but that is not true reality: it is only the reality of general ideas, conventional forms of humdrummery, current editorials ... Average reality begins to rot and stink as soon as the act of individual creation ceases to animate a subjectively perceived texture (Strong Opinions 118; my italics).

This act of "animating a subjectively perceived texture"-a ceaseless "animating" of a "texture"-subjects "true reality" to a kind of constant aestheticizing, a constant writing, painting, scoring, sculpting of subjective perception. Thus for Nabokov the "creative writer ... must possess the inborn capacity not only of recombining but of re-creating the given world." And as a creative writer, he admits, "I tend more and more to regard the objective existence of all events as a form of impure imagination-hence my inverted commas around 'reality'" (Strong Opinions 32). ${ }^{1 "}$ In a certain essential respect, then, to say that The Metamorphosis is a "fantasy" is not to say much. Everything refracted through the eye of the true artist is granted this encomium-and, as is clear from the preceding, "fantasy" is less a descriptive term than one of approbation.

Nabokov's first claim—that The Metamorphosis is a "fantasy"-is thus both doubly right and doubly vacant. On the one hand, it is likely that none of its readers will have experienced a transformation into an insect. On the other hand, everything transmitted by an artist of genius-Proust, Tolstoy, Kafka, or himself, to employ the examples he offers-is by definition a "fantasy." This first and central

\footnotetext{
${ }^{11}$ It may be apt in this connection to think of Pablo Neruda's remark that "the poet who is not a realist is dead; and the poet who is only a realist is also dead" (265).
} 
claim that Nabokov makes may say something about himself as a reader, but it seems to say little about Kafka's story.

\section{The Beetle, or on Genius}

From the generalities of fantasy Nabokov turns to the particularities of Kafka's story. Nabokov begins by asking what is transformed into what, and this requires that he present some entomological facts. The first of these is that Gregor is a beetle, a conclusion that entails a problem of legs. Kafka does not number them, but in their "flimmering" they seem to Gregor a great many. If they are more than six, "from a zoological point of view" Gregor is not an insect (Lectures 258). Nabokov then offers a psychological explanation for the flimmering legs: he (reasonably) notes that for a creature used to two legs, six will seem, the first thing on a groggy morning, a great many. Therefore, Nabokov continues, "we shall assume that Gregor has six legs, that he is an insect" (258). Though the jocular cleaning woman at the end of the tale will call Gregor a "dung-beetle" ("Mistkäfer"), Nabokov observes that this can and should be read as something of the order of a rough term of affection. Nabokov then notes a detail that neatly reflects the distance in temperament between Kafka and himself. Gregor has, he tells his students, "a tremendous convex belly divided into segments and a hard rounded back suggestive of wing cases. In beetles these cases conceal flimsy little wings that can be expanded and then may carry the beetle for miles and miles in a blundering flight. Curiously enough, Gregor the beetle never found out that he had wings under the hard covering of his back. (This is a very nice observation on my part to be treasured all your lives)" (259; cf. Foster 448). To underline this nicety Nabokov would draw the beetle for his students on the blackboard (as he did in the teaching copy of his book). Years later, in 1967, Nabokov was fond enough of this observation to repeat it to an interviewer: ". . neither Gregor nor his maker realized that when the room was being made by the maid, and the window was open, he could have flown out and escaped and joined the other happy dung beetles rolling the dung balls on rural paths" (Strong Opinions 90-91).

That Kafka himself wanted Gregor's form to remain indistinct is made clear by a letter he sent to his publisher Kurt Wolff on October 25th, 1915, in which Kafka worries that the illustrator for the volume (Ottomar Starke) "could want to depict the insect itself. Not that! Please: not that!" (“. . könnte das Insekt selbst zeichnen wollen. Das nicht, bitte das nicht!," Briefe 135). Kafka politely adds that, although he does not wish to impinge upon the creative freedom of the artist, in this case "I must call upon my better knowledge of the story. The insect cannot be drawn. It can't even be shown in the distance" ("Das Insekt selbst kann nicht gezeichnet werden. Es kann aber nicht einmal von der Ferne gezeigt werden," 135). In light of this wish, Nabokov's precise delineation may seem at crosspurposes with one of the effects Kafka wished to achieve. Based as it is, however, on philological attention and entomological acumen, it is not an illegitimate conclusion and, more importantly, it is an account that served to focus his students' attention on the story's minute details.

With the matter of the what of Gregor's titular "transformation" (the term 
Nabokov prefers over the standard English "metamorphosis") settled, Nabokov directs his students to the how. "The change," he says, "though shocking and striking, is not quite so odd as might be assumed at first glance" (Lectures 260). This is a radical declaration, and the reasoning that follows is curious, daring, and less than solid. He reminds his listeners how we are all, in the liminal state between sleeping and waking, subject to strange uncertainties and "fantasies." "Awakening as an insect," says Nabokov, "is not much different from awakening as Napoleon or George Washington"-adding for emphasis, "I knew a man who awoke as the Emperor of Brazil" (260). But the gripping and profoundly unsettling fact about Gregor's awakening-a fact that Nabokov brushes over-is that it is not followed by a second awakening in which Gregor gradually orients himself and finds his body where he left off with it. From this point forward he lives and dies as an insect. What is more, Gregor does not think he is some other person-he thinks he is Gregor and an insect.

Nabokov's next pedagogical step takes the form of a warning against symbolic (or allegorical) readings of the story. He is vehement in his admonitions not to interpret this "transformation"-and The Metamorphosis as a whole-as a religious allegory, a psychological allegory, or as any other kind of allegory. Just as he vehemently rejects symbolic or mythological interpretations in the cases of other treasured works-his own and others-he rejects such interpretations here. "I want to dismiss two points of view," he says. "I want to dismiss completely Max Brod's opinion that the category of sainthood, not that of literature, is the only one that can be applied to the understanding of Kafka's writings. Kafka was first of all an artist, and although it may be maintained that every artist is a manner of saint (I feel that very clearly myself), I do not think that any religious implications can be read into Kafka's genius. The other matter I want to dismiss is the Freudian point of view" (Lectures 255). Athough he concedes that Kafka had a "complex relationship with his father" and does not explicitly refute the psychoanalytic contention that Kafka had a "lifelong sense of guilt," Nabokov says that the "nonsense" of the psychoanalytical approach should be simply "reject[ed]" (Lectures 255-56). On this point Nabokov calls to the bar Kafka himself, specifying that the latter "regarded Freud's theories as very approximate, very rough pictures, which did not do justice to details." For this reason, he concludes, "I should like to dismiss the Freudian approach and concentrate, instead, upon the artistic moment" (Lectures 256).

And yet it is at this point-the point at which Nabokov wishes to "concentrate ... upon the artistic moment"-that his reading of Kafka commits the cardinal sin in his critical canon. It is here that he will fail to "do justice to details." Nabokov can say that Gregor's transformation is "not quite so odd" as it might at first appear because, in a certain sense, he comes to read it as not what it first appears. Gregor is subject to a transformation, but the transformation in Nabokov's reading is less into the bug he detailed and drew for his students than in to a "genius." He states that "the isolation, and the strangeness, of so-called realitythis is, after all, something that characterizes the artist, the genius, the discoverer. The Samsa family around the fantastic insect is nothing else than mediocrity surrounding genius" (Lectures 260; my italics). After Nabokov's admonitions against 
treating the work as a religious or psychological allegory, after his reminders to attend to the divine detail, he makes Kafka's tale into an allegory of the fate of the artist surrounded by uncomprehending mediocrity. The mystery of Gregor's metamorphosis is resolved.

There are two problems involved here, one more pedantic, the other less so. The more pedantic problem is that Nabokov violates his most ardently held credo in succumbing to a fundamentally symbolic reading of a work of art-and not just any work of art, but one that he ranked among the very finest. "I detest symbols and allegories," we read in "On a Book Entitled Lolita" (Annotated Lolita 314). In the list of items offered as advice to an imaginary "budding literary critic" Nabokov writes: "Ask yourself if the symbol you have detected is not your own footprint. Ignore allegories" (Strong Opinions 66). The problem is that in this case-which is not just any case- he does not ignore allegory. His reading is every bit as allegorical as, to choose a celebrated and influential moment in the reception of Kafka's cryptic story, Günther Anders's claim that Gregor is a "Luftmensch," "a man with his head in the clouds," who, in Anders's words, "wants to live as an artist" and therefore is seen as nothing but a "filthy bug" (Anders 40-41; cf. Corngold 68,76).

The less pedantic problem concerns the coordinates of Nabokov's symbolic interpretation. No reasonable reader would refuse Nabokov some latitude in this domain, and none would deny him the right to make exceptions to his symbolic rule or to develop his method. What the reasonable reader will have trouble with is the validity of his symbolic reading as a symbolic reading. Gregor resembles a genius only in the most general and superficial way-not for what he does, or how he thinks, or for his creative acts or creative urges, but merely for the dismissive and uncomprehending manner in which others treat him. As a symbolic reading, this does not satisfy even rather limited criteria. Before his transformation, Gregor was perfectly mediocre (as concerns criteria of artistic gift or genius). After his transformation, there is nothing artistic about him except his sorry lot. And this is a great deal of symbolic weight to lay upon such a fragile base.

What then about the other side of Nabokov's symbolic equation: "mediocrity surrounding genius"? This mediocrity is primarily represented by Gregor's family. His father is unkind, brutish, manipulative, and, as hinted at in the story (he has been skimming off the top of Gregor's salary to make a family nest egg without informing Gregor), he has always been so. Gregor's mother is well intentioned, but weak, frail, and ultimately ineffectual. Whenever she tries to offer some protection or consolation, she cannot get enough air and collapses. Gregor's sister is a far more complicated case, and a far more mysterious one. At the beginning she is gentle and understanding, but over time her heart seems to harden towards her transformed brother. Nabokov deals with this complex and haunting aspect of the story in peremptory fashion. He concedes that "this is a curious note: the domineering sister, the strong sister of the fairy tales, the handsome busybody lording it over the fool of the family, the proud sisters of Cinderella, the cruel emblem of health, youth, and blossoming beauty in the house of disaster and dust" (Lectures 271). Later, he returns to the "hard health of her ruddy adolescence" before deeming her simply a "villain" (Lectures 272; 275). While 
this is not simply false, it is not accurate in the "fairy tale" way Nabokov describes. At the outset of his lectures on literature Nabokov enjoined his students to read the works of art under discussion as "fairy tales" in order to prevent them from finding easy interpretations for complicated stories. The declaration that all great works were great fairy tales was of a pair with his claim that there was "no reading, but only rereading"; careful rereading would reveal the complex relations of the elements of stories in the hands of masterful writers ("Curiously enough, one cannot read a book: one can only reread it" [Lectures 3; Nabokov's italics]). Here, however, Nabokov's recourse to "fairy tale" serves only to lighten his interpretive task. It leads him to make of disturbingly complex characters with paradoxical reactions to an incomprehensible state of affairs (son and brother become insect) simple characters viewed in a schematic and ultimately general light. Gregor's family is credited with no more psychological depth than is to be found in the figures of a fairy tale. That he does not have recourse to biographical interpretation, which would have allowed him an analogous simplification in noting unsettling parallels between Gregor's remarks, experiences, and dreams and those Kafka noted about his own life, does not mitigate this fact. While Gregor's family does not react with anything like compassion or gentleness, it should not be forgotten that within the world of the story he is, after all, a beetle whose scarce utterings and confusing movements they have the greatest difficulty identifying with some enduring core of humanity in Gregor's insect breast. And while they are not ideally attentive, it is wrong to claim, as Nabokov does, that in the days immediately following Gregor's transformation they are "cosily taking it in their-stride" (Lectures 266). Here, as elsewhere, Nabokov's response to the ignominious family is black and white. While Gregor's sister is indeed at the center of this scorn, the intense resentment is generalized until Nabokov makes of it an axiom: "Gregor is a human being in an insect's disguise; his family are insects disguised as people"-and, even more virulently, "The soul has died with Gregor; the healthy young animal [Grete] takes over. The parasites have fattened themselves on Gregor" (Lectures 280; 282).

Nabokov's sensitivity most obviously abandons him in discussing the story's final scene. Nabokov repeatedly noted and reflected upon his inability to appreciate music. In his autobiography, for example, he defines music as "an arbitrary succession of more or less irritating sounds" (Speak Memory 35-36). In his lecture on Kafka, Nabokov claims that "taken in a general sense music, as perceived by its consumers, belongs to a more primitive, more animal form in the scale of arts than literature or painting," and that "the impact music in a generalized and primitive form has on the listener is of a more lowly quality than the impact of an average book or an average picture" (Lectures $277 ; 278$ ). In short, its effects are simply "soothing, lulling, dulling" (Lectures 278). This particular prejudice will lead him to see the final scene through the most simplifying of optics. Grete is playing the violin-which Nabokov describes for his students as "a girl pitifully scraping on a fiddle" (278). There is no justification for this abuse, no reason to deduce that her playing is pitiful or even poor. Though the thoroughly philistine lodgers seem distracted during the performance and try above all to physically approach Grete, this means nothing as concerns her playing. They haven't shown 
themselves to be particularly sensitive thus far in the story, and there is no reason to believe that they are able to appreciate music. At this moment in his reading, Nabokov attributes his own (highly idiosyncratic) view of music to Kafka: "What Kafka felt about music in general is what I have just described: its stupefying, numbing, animal-like quality. This attitude must be kept in mind in interpreting an important sentence that has been misunderstood by some translators. Literally, it reads 'Was Gregor an animal to be so affected by music?'" (278). This is indeed what Gregor says, but Nabokov understands the words without grasping their meaning. Gregor's dream of generosity, of sending his beloved little sister to the conservatory, has vanished. With the indifference to convention that heralds his death, Gregor, moved by the music, shows his insect self. This artistic sensibility and sensitivity-the only such sensitivity Gregor shows in the story and thus, had Nabokov wanted to convince us Gregor was a genius, a crucial piece of the puzzle-is dismissed by Nabokov as merely "animalic" (278). The gentle pathos of Gregor's state and the indeterminable irony of Kafka's tone are elements that Nabokov picks up elsewhere in the story-but not here. ${ }^{12}$

What Nabokov fails to recognize is something fundamental about Kafka and his creations. Being or becoming an animal—or an insect-in Kafka's works is a highly specific affair and involves a process whereby a creature's humanity, for lack of a better word, tends to be augmented and accented. In 1920, Kafka's friend Gustav Janouch brought him an English book, David Garnett's Lady into Fox, which Janouch denounced as having copied the methods Kafka had invented in The Metamorphosis. Kafka immediately rejected the idea: "he did not copy that from me-it is part of our times. We both copied it. Animals are closer to us than men. Those are the bars of the cage." ${ }^{13}$ A week later, Kafka returned to the idea in his talks with Janouch: "each of us lives behind bars that we carry with us wherever we go. This is why there is so much writing about animals. It is an expression of the desire for a free and natural life" (Janouch 43). What Kafka wished to express through his insect and the rest of his animal menagerie was that modern life and language carried their own bars-and ones not easily pulled down. The ape of "A Report to the Academy," the beetle of The Metamorphosis, the mice of "Josephine the Singer," the dog of "The Investigations of a Dog," and the other enigmatic creatures in Kafka's works, all express a longing for "a free and natural life."

At the outset of his lecture, Nabokov links The Metamorphosis with Gogol's "The Overcoat" and distinguishes the two from Stevenson's Dr. Jekyll and Mr.

\footnotetext{
${ }^{12}$ Consider, for example, Nabokov's comment that, "Kafka's art consists in accumulating on the one hand, Gregor's insect features, all the sad detail of his insect disguise, and on the other hand, in keeping vivid and limpid before the reader's eyes Gregor's sweet and subtle human nature" (Lectures 270 ).

${ }^{13}$ In his afterword to Lolita Nabokov employs this same figure of an animal (an ape) in a cage to describe the moment of inspiration that preceded his writing of that work: "The first little throb of Lolita went through me late in 1939 or early in 1940, in Paris, at a time when I was laid up with a severe attack of intercostal neuralgia. As far as I can recall, the initial shiver of inspiration was somehow prompted by a newspaper story about an ape in the Jardin des Plantes, who, after months of coaxing by a scientist, produced the first drawing ever charcoaled by an animal: this sketch showed the bars of the poor creature's cage" (Annotated Lolita 311). This article has never been found, and there is every reason to believe that Nabokov invented it for the occasion.
} 
Hyde. Of the latter he says, "there is no such human pathos, no throb in the throat of the story, none of that intonation of 'I cannot get out, I cannot get out,' said the starling (so heartrending in Sterne's fantasy A Sentimental Journey)" (254). The moment of human pathos represented by Gregor's approaching his sister, this throb in the throat of Kafka's story, is the moment Nabokov uses to advance the suspect theory that here, at last, Gregor's transformation is complete: by succumbing to music he has finally and fully become "animalic" and his metamorphic race has run (cf. Deleuze and Guattari 5-6, 10-11). But more than anything else it shows him deaf to a touching tonality in Kafka's writing. To borrow an epithet from Wordsworth, being an animal in Kafka's worlds is that which is most likely to "humanize [the] soul." But both Nabokov's personal distaste for music and the coordinates of his symbolic interpretation lead him to neglect this.

\section{Parables}

Nabokov's works abound with indications that amidst the misleading paths and deceptive symbols there is something like a unique solution to the problems posed. It is for this reason that he so often compared the composition of his works to riddles and chess problems - to things with a single correct response. This does not mean, however, that all the mysteries have been, or can be, dispelled. Throughout his life Nabokov ardently defended the details of cherished works of art against generalizing interpretations of them. And yet his reading of The Metamorphosis is a glaring case of precisely such an interpretation. Some of this can be attributed to the fact that in the case of Kafka Nabokov may have felt himself on shaky ground in lecturing about a national literary tradition he did not know especially well. But there is more to the matter.

In a posthumously published fragment Kafka once wrote:

Many complain that the words of the wise are always merely parables and of no use in daily life, which is the only life we have. When the sage says: "Go over," he does not mean that we should cross over to some actual place, which we could do anyhow if the labor were worth it; he means some fabulous yonder, something unknown to us, something too that he cannot designate more precisely, and therefore cannot help us here in the very least. All these parables really set out to say merely that the incomprehensible is incomprehensible, and we know that already. But the cares we have to struggle with every day: that is a different matter.

Concerning this a man once said: Why such reluctance? If you only followed the parables you yourselves would become parables and with that rid yourself of all your daily cares.

Another said: I bet that is also a parable.

The first said: You have won.

The second said: But unfortunately only in parable.

The first said: No, in reality: in parable you have lost. (Kafka 457)

Walter Benjamin aptly notes: "Kafka disposed of a rare gift for the creation of parables. Yet his parables are never exhausted by what is explainable; on the contrary, he took every conceivable precaution against their interpretation" ( $\mathrm{Se}$ lected Writings 804 [translation modified]; "Trotzdem erschöpft er sich in dem, was deutbar ist, niemals, hat vielmehr alle erdenklichen Vorkehrungen gegen die Auslegung seiner Texte getroffen" (Gesammelte Schriften 2.422). Benjamin claims that the two surest ways of misinterpreting Kafka's works are interpreting 
them in either a natural or supernatural fashion (or, alternately, in a psychoanalytical or theological fashion), and in this he anticipates Nabokov's warnings (Gesammelte Schriften 2.425). The essence of Kafka's parabolic genius was, for Benjamin, his ability to compose parables with no definite meaning. The more closely they are followed, the more rapidly they recede; their genius resides in their inexhaustibility. Following in Benjamin's footsteps, Adorno wrote that Kafka's parables "express themselves [drückt sich . . aus] not through their expression [Ausdruck] but through their refusal, through their interruption . . Each sentence says: interpret me and none will permit it" (Gesammelte Schriften 10.1.255). And he went on to claim that in Kafka's works "the contemplative relation between text and reader" was shaken "to its very roots" (Prisms 246). More recently, Guy Davenport has written that "signs and symbols have no claim on Kafka, who wrecks tradition rather than trust any part of it" (5), and Werner Hamacher has argued that in Kafka's work tradition is "transformed ... into a giving and an imparting [Geben und Weitergeben] that has no content, no longer has a gift to give beyond giving itself [das keinen Inhalt, keine Gabe mehr gibt, sondern nur dies Geben selber]" (289).

In short, for Kafka's most perceptive readers his symbols are especially notable for their opacity, their indeterminacy, for never being subject to anything like a decisive interpretation. Keats saw Shakespeare as "possess[ing] so enormously" what he called "Negative Capability"-the capacity to remain "in uncertainties, Mysteries, doubts, without any irritable reaching after fact \& reason" (260-61) Kafka does not require that his readers and interpreters renounce fact and reason, but he does ask them to remain in "uncertainties, Mysteries, doubts." One of the most difficult tasks for a good reader and a good writer is to locate symbolic aspects of the work of art and to describe them with a sensitivity that does not reduce them to simple coordinates (such as "genius" vs. "mediocrity"). Nabokov showed great fidelity to the individual details of works of art and defended those works he loved-and wrote-against simplifying symbolic interpretations. And yet his readers should not overlook that in the case of Kafka, whether because of the position from which he gave his lectures (the professorial podium and the expectations of mastery it encourages), because of the extraordinary demands that Kafka's works make upon their readers, or because of Nabokov's preference for determinate if difficult interpretations, he ignored his own injunctions and violated his own interpretive precepts.

\section{Harvard University}

\section{Works Cited}

Adorno, Theodor Wiesengrund. Gesammelte Schriften. Herausgegeben von Rolf Tiedemann unter Mitwirkung von Gretel Adorno, Susan Buck-Morss und Klaus Schultz. 20 vols. Frankfurt am Main: Suhrkamp, 1973-1986.

_. Prisms. Trans. Samuel and Shierry Weber. Cambridge: MIT Press, 1981.

Benjamin, Walter. Gesammelte Schriften. Ed. Rolf Tiedemann and Herman Schweppenhäuser. Frankfurt am Main: Suhrkamp Verlag, 1974-1989. 


\section{COMPARATIVE LITERATURE / 330}

Selected Writings. Volume 2: 1927-1934. Trans. Rodney Livingstone et al. Ed. Michael W. Jennings, Howard Eiland, and Gary Smith. Cambridge: Harvard University Press, 1999.

Boyd, Brian. Vladimir Nabokov. The Russian Years. Princeton: Princeton University Press, 1990.

Calvino, I talo. Mondo scritto e mondo non scritto. A cura di Mario Barenghi. Milano: Oscar Mondadori, 2002.

Canetti, Elias. Der andere Prozeß. Kafkas Briefe an Felice. Munich: Hanser, 1969.

Corngold, Stanley. Franz Kafka: The Necessity of Form. Ithaca and London: Cornell University Press, 1988.

Davenport, Guy. The Hunter Gracchus, And Other Papers on Literature and Art. Washington: Counterpoint, 1996.

de la Durantaye, Leland. Style is Matter. The Moral Art of Vladimir Nabokov. Ithaca: Cornell University Press, 2007.

Deleuze, Gilles, and Félix Guattari. Kafka. Pour une literature mineure. Paris: Minuit, 1975.

Kafka: Toward a Minor Literature. Trans. Dana Polan. Minneapolis: University of Minnesota Press, 1986

Dickens, Charles. David Copperfield. Oxford and London: Oxford University Press, 1999.

Eschwege, Heinz von (Heinz von Lichberg). Die verfluchte Gioconda: Grotesken. Darmstadt: FalkenVerlag, 1916.

Field, Andrew. Nabokov: His Life in Part. New York: Viking, 1977.

Foster, John Burt Jr. "Nabokov and Kafka." The Garland Companion to Vladimir Nabokov. Ed. Vladimir Alexandrov. New York: Garland Publishing Inc., 1995. 444-51.

Hamacher, Werner. Entferntes Verstehen. Studien zu Philosophie und Literatur von Kant bis Celan. Frankfurt am Main: Suhrkamp, 1998.

Hyde, G.M. Vladimir Nabokov: America's Russian Novelist. London: Marion Boyars, 1977.

Janouch, Gustav. Gespräche mit Kafka. Frankfurt am Main: Fischer, 1968.

Kafka, Franz. Briefe 1902-1924. Hrsg. von Max Brod. Frankfurt am Main: Suhrkamp, 1966.

- The Complete Prose. Trans. Willa and Edwin Muir. Ed. Nahum N. Glatzer. New York: Schocken, 1971.

Der andere Prozeß. Kafkas Briefe an Felice. Munich: Hanser, 1969.

Keats, John. Selected Poems and Letters. Ed. Douglas Bush. Boston: Houghton Mifflin, 1967.

Maar, Michael. "Curse of the First Lolita. Heinz von Lichberg and the Pre-History of the Nymphet." The Times Literary Supplement 2 Apr. 2004: 13-15.

- The Two Lolitas. New York: Verso, 2005.

“Was wußte Nabokov?" Frankfurter Allgemeine Zeitung 19 Mar. 2005: 37.

Nabokov, Vladimir. Ada, or Ardor: A Family Chronicle. 1969. New York: Vintage International, 1990.

The Annotated Lolita. Ed. Alfred Appel, Jr. 1970. Rev. Ed. New York: Vintage International, 1991.

Bend Sinister. 1949. New York: Vintage International, 1990.

"Conclusive Evidence." The New Yorker 28 Dec. 1998-4 Jan. 1999: 124-33.

The Defense. Trans. Michael Scammell and Vladimir Nabokov. 1964. New York: Vintage International, 1989

Interview with Ainne Guérin. L'Express (Paris). 26 Jan. 1961: 26-27.

. Interview with Pierre Dommergues. Les langues modernes 1 (Jan.-Feb. 1968): 92-102.

Invitation to a Beheading. Trans. Dmitri Nabokov and Vladimir Nabokov. 1959. New York: Vintage International, 1989.

- Lectures on Literature. Ed. Fredson Bowers. New York: Harcourt Brace Jovanovich, 1980.

Look at the Harlequins! 1974. New York: Vintage International, 1990.

The Nabokov-Wilson Letters: Correspondence Between Vladimir Nabokov and Edmund Wilson, 1941-1971. Ed. Simon Karlinsky. 1979. New York: Harper Colophon, 1980. 
- Pale Fire. 1962. New York: Vintage International, 1989.

Selected Letters 1940-1977. Ed. Dmitri Nabokov and Matthew J. Broccoli. New York: Harcourt Brace Jovanovich, 1989.

Speak, Memory: An Autobiography Revisited. 1967. New York: Vintage International, 1989.

Strong Opinions. 1973. New York: Vintage International, 1990.

. "The Tragedy of Tragedy." The Man from the U.S.S.R. and Other Plays. Trans. and ed. Dmitri Nabokov. New York: Harcourt Brace Jovanovich, 1984. 323-42.

. "Wer ist der Lolita-Autor? Ein Interview mit Vladimir Nabokov." Interview with Manfred George. Die Zeit. 17 April 1959: 6.

Neruda, Pablo. Memoirs. Penguin Books, 1978.

Proust, Marcel. A la recherche du temps perdu. Ed. Jean-Yves Tadié. 4 vols. Paris: Gallimard, 1987-89.

Schickert, Katharina. Der Schutz literarischer Urheberschaft im Rom der klassischen Antike. Tübingen: Mohr Siebeck, 2005.

Schiff, Stacy. Véra (Mrs. Vladimir Nabokov). New York: Random House, 1999.

Urban, Thomas. Vladimir Nabokov. Blaue Abende in Berlin. Berlin: Propyläen Verlag, 1999.

Zimmer, Dieter E. Nabokovs Berlin. Berlin: Nicolai Verlag, 2001. 
Copyright of Comparative Literature is the property of Comparative Literature and its content may not be copied or emailed to multiple sites or posted to a listserv without the copyright holder's express written permission. However, users may print, download, or email articles for individual use. 